\title{
Factors Affecting Liquidity of Banks: Empirical Evidence from the Banking Sector of Pakistan
}

\author{
Syed Quaid Ali Shaha, Imran Khana, Syed Sadaqat Ali Shaha, \\ Muhammad Tahir ${ }^{\mathrm{a}} \bowtie$ \\ ${ }^{a}$ Department of Management Sciences, COMSATS Institute of Information Technology,
} Pakistan

\begin{abstract}
This research investigates factors affecting liquidity of banks operating in Pakistan. Spanning from 2007 through 2016 the sample of the study includes 23 banks by employing relevant econometric specifications. The findings reveal that the internal factors such as capital adequacy ratio (CAR), cost of funds and bank size are statistically significant but differently related to the liquid asset to total asset ratio and to the total loans to total deposit ratio, respectively. The study finds that external or macro factors, such as GDP is statistically significant but affect liquidity of the banks differently. Unemployment, another external factor, also impact liquidity of banks very differently but it is statistically significant in the first measure of liquidity and statistically insignificant in the second measure of banks' liquidity. Further, the results revealed that profitability is insignificantly related to liquidity while the relationship between deposits and bank liquidity is negative and statistically significant.
\end{abstract}

Keywords: Liquidity, Capital Adequacy Ratio, Funding Cost, Bank Size, Pakistan

$\begin{array}{lll}\text { Received: } & \text { Accepted revised version: } & \text { Published: } \\ \text { 18 October 2017 } & \text { 20 April 2018 } & \text { 30 June 2018 }\end{array}$

Suggested citation: Shah, S.Q.A, Khan, I, Shah, S.S.A \& Tahir, M. (2018). Factors affecting liquidity of banks: Empirical evidence from the banking sector of Pakistan. Colombo Business Journal. (9)1, 1-18

DOI: http://doi.org/10.4038/cbj.v9i1.20

(C) 2018 The Authors. This work is licenced under a Creative Commons Attribution 4.0 International Licence which permits unrestricted use, distribution, and reproduction in any medium, provided the original work is properly cited.

凶tahirm@ciit.net.pk.; iD https://orcid.org/0000-0002-9198-0846 


\section{Introduction}

The banking sector plays a vital role in an economy by engaging as an intermediary between surplus and deficit units, respectively, other than playing a pivotal role in the execution of different valuable activities on both sides of the balance sheet. The statement of financial position supplies very important information to interested stakeholders. For instance, the assets side, besides other current and fixed assets, includes loans of the banks while the liabilities side show deposits made by the customers, among other things.

The global financial crisis of 2007-2008 renewed the importance of liquidity. Prior to the crisis, most researchers had considered liquidity risk as a secondary risk in banking literature (Matz, \& Neu, 2007). Retaining liquidity (both High Quality Liquid Assets, HQLA, as well as Net Stable Funding Ratio, NSFR, as per Basel Accords) at banks has since been implemented by the country's central bank. Problems arise when banks invest short term liquid assets into long term liquid assets, thereby creating a liquidity shortfall for banks and vice versa.

Financing of liquid liabilities from illiquid assets is termed as liquidity creation which results in uplifting of economic value by the banks (Sabahat, 2017) which can also result in liquidity risk when banks involve in multiple activities (Arif \& Anees, 2012). Stated otherwise, banks face liquidity problems when they get involved in investing in long-term illiquid assets or holding relative liquid liabilities that could be called upon at short notice (Distinguin, Roulet, \& Tarazi, 2013). Rapid and unanticipated withdrawals by customers results in bank run, or in other words, and emergence of liquidity shortfall for them (N. Ahmed, Ahmed, \& Naqvi, 2011). Capital or liquidity buffer held by bank act as cushion against any liquidity shortfall (Bhattacharya \& Thakor, 1993) which is managed by holding a buffer of high liquid assets such as cash and government securities (Bonner, Van Lelyveld, \& Zymek, 2015). However, banks with a huge capital buffer culminate and reduce the liquidity. The banks are exposed to more risk when they create more liquidity (Diamond \& Rajan, 2001). Apart from the deteriorating performance of the banks, liquidity problems also exacerbate banks' reputation (Jenkinson, 2008). Poor liquidity or minimum level of liquidity results in losing depositors' trust, and the banks' status may be spoiled which can also attract high penalties from the regulators. Therefore, it is of utmost important for banks to maintain adequate liquidity levels. 
The Pakistan banking sector also became a victim of liquidity shortfalls because of credit demand from the public sector enterprises and huge amounts of funds borrowed by the government of Pakistan, to meet its fiscal needs, due to which it became difficult for the State Bank of Pakistan (SBP) to manage liquidity in Pakistan's banking system (Arif \& Anees, 2012). The objective of the present research study is to identify the impact of internal factors as well external factors on liquidity of the banking sector of Pakistan by considering 23 commercial banks operating in Pakistan by employing relevant econometric specifications.

The remainder of the paper is structured as follows. The next section discusses the banking sector of Pakistan followed by a discussion on the relevant literature. Then methodology and data of the study are presented. Empirical findings are explained next. The paper concludes with direction for further research.

\section{Theoretical Background - Pakistan Banking Sector}

The Pakistan Banking industry has a history of over more than 70 years. This history includes formations, privatisation (of 1960's till mid1970's), nationalisation of the banking sector in the 1970's which continued till late 1980's when the government decided to reform the banking sector of the country by launching privatisation of the banks. After independence, the country's central bank, SBP, was established on July $1^{\text {st }}, 1948$, which assumed the supervisory and monetary policy powers of the Reserve Bank of India. Later, modifications were made to improve the control and function of $\mathrm{SBP}^{1}$.

The number of banks grew rapidly in the 1950's and 1960's. The performance of the banking sector, however, remained below par by supplying credit to privileged class and remaining as insufficient to meet needs of the business community, besides failing to serve other starving sectors of the economy (Tahir, Shah, Afridi, 2016). To trickle banking services equally and to ensure loans to the underprivileged ones, the government in 1974, announced nationalisation of all banks. Private and foreign financial institutions were discouraged through Acts promulgated by the government. The performance of the banking sector improved considerably by supplying loans to large as well as small and medium enterprises at affordable interest rates $^{2}$. Multiple loan programmes were launched to ensure

\footnotetext{
${ }^{1}$ For history and evolution of State Bank of Pakistan, visit www.sbp.org.pk

${ }^{2}$ For an insight on loans to different sectors of the economy, see Financial Stability Review issued by the State Bank of Pakistan as well as Pakistan Economic Survey issued by the Ministry of Finance on annual basis.
} 
inclusive growth, hence the banking sector as well as the national economy experienced an expansion of the banking services and an increase in the growth rate of the economy ${ }^{3}$.

The performance of the banking sector started to deteriorate when banks were overemployed and loans started to flow towards privileged ones which caused most of the loans to be either unpaid or become default due to political interventions. Therefore, to ensure competitiveness of the banking sector and to bring the banking sector at par with international best practices the government in late 1980's and early 1990's launched denationalisation of the banks. The low performance of the banking sector transformed nationalised banks into privatised banks (Ahmad, Malik, \& Humayoun, 2010).

The banking sector in the post privatisation period witnessed massive growth in role of the banking sector. For instance, the banking reforms attracted private banks and foreign banks, besides improving quality of banking products and services, induced professionalism and signified the role of information technology to operate efficiently and improve the aggregate profitability of banks.

Figure 1: Structure of the Pakistan Banking System

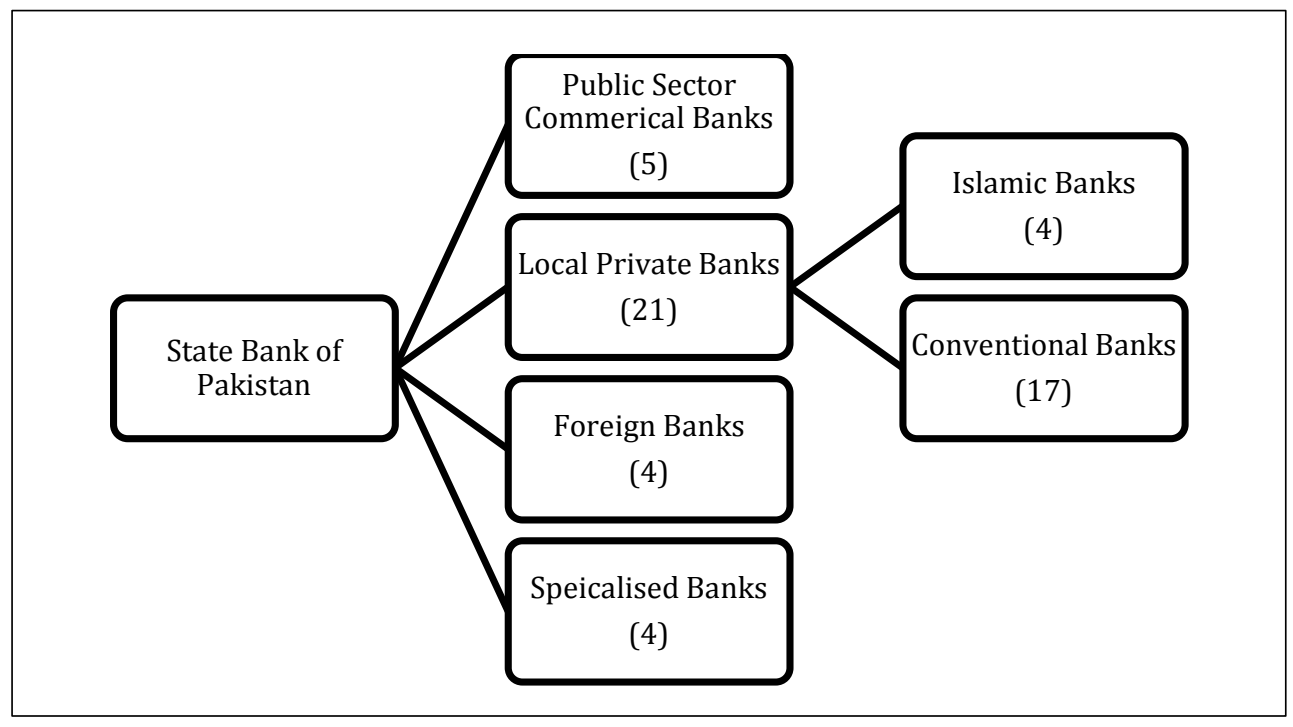

\footnotetext{
${ }^{3}$ For information on the growth of loans please see Financial Stability Review issued by the State Bank of Pakistan.
} 
The Pakistan banking industry is regulated and supervised by its central bank, SBP, under the set prudential regulations. The progress in the banking sector is because of the heedful management of SBP. Excluding DFIs and non-financial companies, SBP (2017) in its quarterly performance review revealed the total number of banks operating in Pakistan is 34 which are structurally divided into four categories, namely, public commercial banks, local private banks, foreign banks and specialised banks. The structure of the Pakistan banking system is depicted in Figure 1.

\section{Literature Review}

The importance of liquidity has not been emphasised by the financial institutions. Similarly, Financial institutions, for their own interest and the entire financial system, should hold more liquidity than they tend to hold in the past.

The banks have access to financial markets but access of small banks is less as compared to large banks because smaller banks are not well known to financial markets as compared to their large counterparts. The access to liquidity and external sources of financing depends on the size of the bank and vary from bank to bank (Alger \& Alger, 1999).

The bank size has a significant impact on liquidity of banks (Delechat, Arbelaez, Muthoora, \& Vtyurina, 2012; Bonfim \& Kim, 2012; Bonner et al., 2015; Dinger, 2009). Contrarily, Aspachs Nier, and Tiesset (2005) found that bank size has no significant influence on banks' liquidity. Simultaneously, the studies of Choon, Hooi, Murthi, Yi, and Shven (2013), Dinger (2009), Singh and Sharma (2016), in their research articles exposed that bank size has a significant influence on the liquidity of the bank but in a negative way. It implies that larger the bank size lower will be liquidity with banks; a negative association, stated otherwise.

Higher earnings represents a high flow of funds to meet liquidity needs while poor earnings lead to less available cash which may raise liquidity turbulence at time of demand deposits. Furthermore, a bank with low profitability discourages potential lenders to provide funds because of chances to become solvent. The studies conducted by Choon et al. (2013), Singh and Sharma, (2016), Lartey Antwi, and Boadi (2013), and Vodova (2013), show profitability as a variable that positively and significantly influence banks' liquidity. However, the finding of Delechat et al. (2012) indicates that banks liquidity is negatively influenced by 
profitability. Simultaneously, Aspachs et al. (2005) exposed the insignificant effect of profitability on bank liquidity.

According to the findings of Dinger (2009), there is an inverse relationship between deposits and bank's liquidity, which means rise in bank deposits results in the reduction of its liquidity. Moussa (2015) revealed that deposits have an insignificant impact on banks' liquidity. Bonner et al. (2015) and Singh and Sharma (2016) found that there is a positive influence of deposits on banks' liquidity. Arif and Anees (2012) also argued that banks face liquidity problems when deposits in banks are withdrawn unexpectedly.

Distinguin et al. (2013) conducted a study on US and European banks to analyse the relationship between bank capital and liquidity for the period of 20002006. The study revealed that banks reduce their capital in creation of liquidity or when they bump into illiquidity. The study of Singh and Sharma (2016) depicts positive and significant association between banks capital and banks liquidity. Exploring the linkage between capital and liquidity creation, Berger and Bouwman (2009) presented that higher capital leads to liquidity creation of banks. High capital of the bank provides easiness in risk absorption. Thus, backed by literature, bank capital has influence on banks' liquidity.

Alger and Alger (1999), Bunda and Desquilbet (2008), Munteanu (2012), and Singh and Sharma (2016) used cost of funds in their studies in order to investigate its impact on liquidity of banks. The study conducted by Alger and Alger (1999) found a significant impact of funding cost on banks liquidity. The study of Singh and Sharma (2016) found no significant association between liquidity and funding cost. Alger and Alger (1999) and Munteanu (2012) explained that banks need to invest more in liquid assets if its funding cost goes up, which means the banks should not rely on interbank funds if liability cost goes up, but the banks should invest in liquid assets which will result in liquidity. When depositors suddenly withdraw cash, it forces banks to borrow from the interbank market or central bank, as a last resort. Banks become less dependent on other external sources of funding when they hold adequate liquid assets. Thus, increase in cost of funds lead the banks to maintain high liquid assets.

The literature has shown mixed results for the relationship between GDP and liquidity of banks (for instance, Valla, Saes-Escorbiac, \& Tiesset, 2006; Rauch, Steffen, Hackethal, \& Tyrell, 2010; Moussa, 2015). For example, the study of 
Bunda and Desquilbet (2008) show that the impact of Gross Domestic Product (GDP) is positive on liquidity of banks. The impact of GDP on liquidity of banks, however, can also be negative (Chen \& Phuong, 2014). In case of the impact of unemployment on liquidity of banks, the study of Horvath, Seidler, and Weill (2014) shows that the impact of unemployment on bank liquidity is negative which means that high rate of unemployment affects liquidity of the banks. It is revealed that the demand by customers for loans declines with the rise in unemployment, thereby impacting the overall bank portfolio.

Based on this literature, this study intends to investigate internal and external factors affecting liquidity of banks operating in Pakistan. The internal factors or bank specific variables taken into consideration are capital adequacy ratio, deposits, profitability, funding cost and bank size. The external or macro factors impacting liquidity of banks are GDP and unemployment. The next section explains data and methods employed to carry out the study.

\section{Data and Methodology}

\section{Specification of Models}

The liquidity of banks can be affected by various factors. In literature, various factors are identified as influencing banks' liquidity. The present study is conducted to investigate the internal as well as external factors that influence liquidity of banks operating in Pakistan. The variables incorporated in the study are bank size, cost of funds, deposits, GDP, unemployment, capital adequacy, and profitability. Some of the studies that identified the factors impacting banks liquidity are Bonfim and Kim (2012), Bonner et al. (2015), Singh and Sharma (2016), and Munteanu (2012). The following models are specified for the purpose of analysis. This study has taken into two measures of liquidity to assess the impact of internal factors as well as external factors on liquidity of banks over the period of analysis.

$$
\begin{gathered}
\mathrm{LIQ1}_{\mathrm{it}}=\beta_{0}+\beta_{1} \mathrm{ROA}_{\mathrm{it}}+\beta_{2} \mathrm{COF}_{i t}+\beta_{3} \mathrm{LNTA}_{i t}+\beta_{4} \mathrm{DEP}_{i t}+\beta_{5} \mathrm{CAR}_{i t}+\beta_{6} \mathrm{GDP}_{i t} \\
+\beta_{7} \mathrm{UNEM}_{i t}+\mathrm{U}_{i t} \\
\mathrm{LIQ2}_{\mathrm{it}}=\beta_{0}+\beta_{1} \mathrm{ROA}_{i t}+\beta_{2} \mathrm{COF}_{i t}+\beta_{3} \mathrm{LNTA}_{i t}+\beta_{4} \mathrm{DEP}_{i t}+\beta_{5} \mathrm{CAR}_{i t}+\beta_{6} \mathrm{GDP}_{i t} \\
+\beta_{7} \mathrm{UNEM}_{i t}+\mathrm{U}_{i t}
\end{gathered}
$$

In the first model, liquidity has been measured with liquid assets to total assets of the banks, whilst in the second model total loans to total deposits ratio has been 
considered to achieve greatest precision. The two models are applied to view the impact on liquidity by the same set of explanatory variables from two different perspectives. For instance, the former takes into account liquid assets while the latter presents us the impact on liquidity with loans of the banks.

$\beta_{1}, \beta_{2} \ldots \beta_{7}$ in Models 1 and 2 are coefficients of the variables; $U$ in both equations are error terms; $i$ and $t$ represent cross-sectional and time dimensions of the variables. The dependent variable is liquidity, measured by two different ratios of banks. Table 1 presents complete information on measurements of the variables.

Table 1: Description of Variables

\begin{tabular}{lll}
\hline Variable & Measurement & Notation \\
\hline Liquidity & Liquid assets/total assets & LIQ1 \\
Liquidity & Total loans/total deposits & LIQ2 \\
Bank size & Log of total assets & LNTA \\
Profitability & Return on assets & ROA \\
Funding cost & Total interest expense/total liabilities & COF \\
Deposits & Deposits/total assets & DEP \\
Capital adequacy ratio & Tier-1 capital & CAR \\
Gross domestic product & Annual GDP & GDP \\
Unemployment & Unemployment rate & UNEM \\
\hline
\end{tabular}

\section{Sample and Data Sources}

The overall banking sector of Pakistan is considered to analyse the influence of internal factors as well external factors on banks liquidity. Due to the unavailability of data on respective variables and mergers and acquisitions in the banking sector, 11 banks are skipped in this research, so the remaining 23 banks are selected for analysis. Data is collected from 2007 to 2016 and hence the total numbers of observations are 230. The sample consists of public sector commercial banks, conventional banks, Islamic banks and specialised banks operating inside Pakistan. The data have been obtained from annual reports published by respective banks and, as supplementary, from the website of SBP, World Development Indicator (WDI) as well as Business Recorder. 


\section{Estimating Methodology}

The nature of the data used is basically panel as there are time as well as cross sectional dimensions. For the estimation of the panel data, there are two widely used models in literature such as fixed effects and random effects modelling procedures. Fixed effect modelling is appropriate if there is serial correlation between the error term of the model and the independent variables. Similarly, on the other hand, the random effects modelling procedure is more suitable in the absence of serial correlation between the explanatory variables and the error term. However, in the case of panel data, there are always chances that error term and explanatory variables may be correlated. It implies that the fixed effects modelling would be preferred over the random effects modelling. However, the decision regarding choosing between the random and fixed effects modelling would be carried out using the Hausman test. The results of the Hausman test reported in the bottom of Table 4 suggest to use the fixed effects model instead of the random effects model. Therefore, the fixed effects model is used to estimate the models.

\section{Analysis and Results}

\section{Descriptive Statistics}

This section contains empirical results. In the first instance, descriptive statistics are reported in order to understand the behaviour of the data over the study period. In other words, descriptive statistics gives a summarised picture of the sample data. Descriptive statistics are provided in the Table 2.

Table 2: Descriptive Statistics

\begin{tabular}{lccccccccc}
\hline & LIQ1 & LIQ2 & CAR & COF & DEP & LNTA & ROA & GDP & UNEM \\
\hline Mean & 0.431 & 0.835 & 0.148 & 0.051 & 0.736 & 12.259 & 0.010 & 3.675 & 5.510 \\
Median & 0.427 & 0.577 & 0.116 & 0.049 & 0.770 & 12.372 & 0.013 & 3.951 & 5.710 \\
Max. & 0.776 & 12.889 & 0.568 & 0.097 & 0.908 & 14.688 & 0.051 & 5.741 & 6.240 \\
Min. & 0.169 & 0.201 & 0.002 & 0.020 & 0.046 & 0.098 & -0.090 & 1.607 & 4.060 \\
Std. Dev. & 0.126 & 1.444 & 0.097 & 0.016 & 0.155 & 1.181 & 0.021 & 1.344 & 0.617 \\
Obs. & 230 & 230 & 230 & 230 & 230 & 230 & 230 & 230 & 230 \\
\hline
\end{tabular}

This section of the paper presents descriptive statistics in order to understand the behaviour of data over the study period. The statistics show the mean value of 0.431 for the variable LIQ and a value of 0.835 for the variable LIQ2, indicating 
that banks in Pakistan, on average, hold, respectively, $43 \%$ and $83.5 \%$ of liquidity buffer. Simultaneously, the maximum liquidity buffers that banks maintain in Pakistan are 0.776 and 12.89 , respectively. Furthermore the minimum values that banks maintain are 0.169 and 0.201 respectively.

Over the period of study banks in Pakistan retain around $15 \%$ of capital adequacy ratio (CAR). This ratio is above the minimum CAR of $8 \%$ imposed by the State Bank of Pakistan. In case of cost of funding (COF), the study reveals that the funding cost is around 5\% which remained as high as 0.09 and as low as 0.02 for banks in Pakistan. The banks attracted large deposits from customers during the period 2007 through 2016. The mean value of deposit is around 74\%, indicating its health over the period which remained as high as 0.91 and as low as 0.046 . For bank size (LNTA) the mean value remained at around 12.26 which has remained as high as 14.7 and as low as 0.098. Furthermore, the mean value of GDP stands at 3.67 whilst the mean value of unemployment remains at 5.51, respectively. The maximum value of GDP reflects the true picture because Pakistan's GDP during the period of study reached as high as around $5.6 \%$. Similarly the maximum value of 6.2 for unemployment, too, shows almost the true picture because unemployment in Pakistan reached as high as $6 \%$ during the same period. The minimum values for GDP and unemployment remained at around 1.6 and 4, respectively.

Banks can remain viable only if they sustain their profitability. For measuring profitability of the banks, ROA has been taken into account in order to show its performance over the sample period. The mean value of ROA as the study reveals, is 0.01 which remained as high as 0.05 and as low as -0.090 . The negative value of ROA is true because in the period 2007 through 2012 banks experienced heavy losses due to which mergers and acquisitions happened in the banking sector (for instance, HSBC Mergers and Acquisitions (M\&A) with Meezan Bank and most recently M\&A of Barclay bank with Habib Bank). The dispersion from mean is gauged by way of standard deviation. Highest dispersion is on LIQ2 having standard deviation value 1.4 and lowest dispersion is of COF with value of 0.016 respectively.

\section{Correlation Analysis}

The strength of association among variables, normally, is reflected in the correlation matrix. The strongest correlation, however, is undesirable due to the 
problem of multicollinearity which violates the assumption of OLS. The correlation analysis for two measures of liquidity in our study is presented in Table 3.

Table 3 shows mixed results for the two measures of liquidity. For instance, in case of liquid assets to total assets ratio (LIQ1) it is revealed that bank liquidity, besides being statistically significant, is positively correlated with deposits ratio (DEP), bank size (LNTA), GDP, unemployment (UNEMP) and the profitability of banks (ROA) over the period of analysis. Cost of funding (COF), nevertheless, is negatively correlated but statistically significant in contrast to capital adequacy ratio (CAR) which negatively correlated but is statistically insignificant. Simultaneously, in case of total loans to total deposits ratio (LIQ2) the findings of correlation analysis reveal that capital adequacy ratio, bank size and profitability remain positively correlated with liquidity of banks in Pakistan whilst cost of funding, deposits, GDP, UNEMP remained negatively correlated with liquidity of banks during the sampled study. In terms of statistical significance, the findings show that CAR, DEP, GDP and ROA are statistically significant in contrast to COF, UNEMP and LNTA which are statistically insignificant. The highest correlation is between bank size (LNTA) and profitability (ROA) of banks, that is 0.567 . Evidence of strong correlation among the variables taken into the study was not found.

\section{Regression Analysis}

The regression results of the balanced panel data are presented in Table 4. Further, the decision to employ fixed effect estimation technique was taken after conducting the Hausman test. Fixed effect estimation technique is also prioritised because it produces consistent results as well as robustness of the estimation, unlike random effect estimation technique. So, because the value of Chi-square is less than $5 \%$ significance level, fixed effects are employed for the sample period. The results are shown in Table 4.

The results of the regression show that the two ratios; liquid assets to total assets and total loans to total deposits, taken into the study show mixed results. For example, although statistically significant, capital adequacy ratios are differently related to the dependent variables LIQ1 and LIQ2, respectively. When banks hold high quality liquid assets it is not difficult for banks to hold sufficient capital as reserve, to serve the function of the banks. Contrarily, relying more on supplying loans against deposits of the banks results in negative consequences for the banks. Banks find it difficult to meet capital requirements when they indulge in excessive 
Table 3: Correlation Matrix

\begin{tabular}{|c|c|c|c|c|c|c|c|c|c|}
\hline & LIQ1 & LIQ2 & CAR & $\mathrm{COF}$ & DEP & LNTA & ROA & GDP & UNEM \\
\hline LIQ1 & 1.000 & & & & & & & & \\
\hline LIQ2 & $\begin{array}{l}-0.382 * * * \\
(0.000)\end{array}$ & 1.000 & & & & & & & \\
\hline CAR & $\begin{array}{l}-0.025 \\
(0.709)\end{array}$ & $\begin{array}{l}0.135^{* *} \\
(0.038)\end{array}$ & 1.000 & & & & & & \\
\hline $\mathrm{COF}$ & $\begin{array}{l}-0.126^{*} \\
(0.054)\end{array}$ & $\begin{array}{l}-0.087 \\
(0.189)\end{array}$ & $\begin{array}{l}-0.014 \\
(0.828)\end{array}$ & 1.000 & & & & & \\
\hline DEP & $\begin{array}{l}0.292 * * * \\
(0.000)\end{array}$ & $\begin{array}{l}-0.777 * * * \\
(0.000)\end{array}$ & $\begin{array}{l}-0.471 * * * \\
(0.000)\end{array}$ & $\begin{array}{l}0.070 \\
(0.290)\end{array}$ & 1.000 & & & & \\
\hline LNTA & $\begin{array}{l}0.407 * * * \\
(0.000)\end{array}$ & $\begin{array}{l}0.108 \\
(0.102)\end{array}$ & $\begin{array}{l}-0.507 * * * \\
(0.000)\end{array}$ & $\begin{array}{l}-0.384 * * * \\
(0.000)\end{array}$ & $\begin{array}{l}0.249 * * * \\
(0.000)\end{array}$ & 1.000 & & & \\
\hline ROA & $\begin{array}{l}0.290 * * * \\
(0.000)\end{array}$ & $\begin{array}{l}0.174 * * * \\
(0.008)\end{array}$ & $\begin{array}{l}-0.071 \\
(0.277)\end{array}$ & $\begin{array}{l}-0.499 * * * \\
(0.000)\end{array}$ & $\begin{array}{l}-0.149 * * \\
(0.023)\end{array}$ & $\begin{array}{l}0.567 * * * \\
(0.000)\end{array}$ & 1.000 & & \\
\hline GDP & $\begin{array}{l}0.318^{* * *} \\
(0.000)\end{array}$ & $\begin{array}{l}-0.125^{*} \\
(0.058)\end{array}$ & $\begin{array}{l}0.003 \\
(0.959)\end{array}$ & $\begin{array}{l}-0.475 * * * \\
(0.000)\end{array}$ & $\begin{array}{l}0.011 \\
(0.864)\end{array}$ & $\begin{array}{l}0.248 * * * \\
(0.000)\end{array}$ & $\begin{array}{l}0.189 * * \\
0.004\end{array}$ & 1.000 & \\
\hline UNEM & $\begin{array}{l}0.213 * * * \\
(0.001)\end{array}$ & $\begin{array}{l}-0.012 \\
(0.853)\end{array}$ & $\begin{array}{l}-0.037 \\
(0.573)\end{array}$ & $\begin{array}{l}-0.046 \\
(0.491)\end{array}$ & $\begin{array}{l}0.038 \\
(0.569)\end{array}$ & $\begin{array}{l}0.109 * \\
(0.098)\end{array}$ & $\begin{array}{l}0.045 \\
(0.493)\end{array}$ & $\begin{array}{l}0.032 \\
(0.624)\end{array}$ & 1.000 \\
\hline
\end{tabular}

Notes: 1 . The numbers in parentheses present the probability.

2. $*$, ** and $* * *$ represents statistical significance at $10 \%, 5 \%$ and $1 \%$. 
Table 4: Main Regression Results

\begin{tabular}{|c|c|c|c|c|}
\hline $\begin{array}{l}\text { Coefficients } \\
\text { Variable }\end{array}$ & LIQ1 & LIQ1 & LIQ2 & LIQ2 \\
\hline $\mathrm{C}$ & $\begin{array}{l}-1.005^{* * *} \\
(0.099)\end{array}$ & $\begin{array}{l}-1.197 * * * \\
(0.143)\end{array}$ & $\begin{array}{l}2.884 * * * \\
(0.166)\end{array}$ & $\begin{array}{l}3.530 * * * \\
(0.235)\end{array}$ \\
\hline CAR & $\begin{array}{l}0.542 * * * \\
(0.088)\end{array}$ & $\begin{array}{l}0.560 * * * \\
(0.099)\end{array}$ & $\begin{array}{l}-1.358 * * * \\
(0.093)\end{array}$ & $\begin{array}{l}-1.585 * * * \\
(0.159)\end{array}$ \\
\hline $\mathrm{COF}$ & $\begin{array}{l}0.088 * * * \\
(0.031)\end{array}$ & $\begin{array}{l}0.054 * * \\
(0.022)\end{array}$ & $\begin{array}{l}-0.164 * * * \\
(0.044)\end{array}$ & $\begin{array}{l}-0.087 * * \\
(0.040)\end{array}$ \\
\hline DEP & $\begin{array}{l}-0.163 * * \\
(0.059)\end{array}$ & $\begin{array}{l}-0.138 * * * \\
(0.049)\end{array}$ & $\begin{array}{l}-0.642 * * * \\
(0.131)\end{array}$ & $\begin{array}{l}-0.707 * * * \\
(0.100)\end{array}$ \\
\hline LNTA & $\begin{array}{l}0.139 * * * \\
(0.008)\end{array}$ & $\begin{array}{l}0.141 * * * \\
(0.013)\end{array}$ & $\begin{array}{l}-0.146 * * * \\
(0.007)\end{array}$ & $\begin{array}{l}-0.173 * * * \\
(0.020)\end{array}$ \\
\hline ROA & $\begin{array}{l}0.339 \\
(0.405)\end{array}$ & $\begin{array}{l}0.428 \\
(0.392)\end{array}$ & $\begin{array}{l}0.941 \\
(0.721)\end{array}$ & $\begin{array}{l}0.359 \\
(0.587)\end{array}$ \\
\hline GDP & $\begin{array}{l}0.011^{*} \\
(0.006)\end{array}$ & & $\begin{array}{l}-0.024 * * * \\
(0.007)\end{array}$ & \\
\hline UMEM & & $\begin{array}{l}0.014 * * \\
(0.007)\end{array}$ & & $\begin{array}{l}-0.015 \\
(0.011)\end{array}$ \\
\hline $\mathrm{R}^{2}$ & 0.787 & 0.787 & 0.735 & 0.730 \\
\hline Adjusted $\mathrm{R}^{2}$ & 0.757 & 0.757 & 0.698 & 0.693 \\
\hline Prob(F-statistic) & 0.000 & 0.000 & 0.000 & 0.000 \\
\hline Hausman Test & $\begin{array}{l}\text { Chi-Sq. } 46.61 \\
\text { Chi-Sq. d.f } 6 \\
\text { Prob } 0.000\end{array}$ & $\begin{array}{l}\text { Chi-Sq. } 55.68 \\
\text { Chi-Sq. d.f } 6 \\
\text { Prob } 0.000\end{array}$ & $\begin{array}{l}\text { Chi-Sq. } 31.46 \\
\text { Chi-Sq. d.f } 6 \\
\text { Prob 0.000 }\end{array}$ & $\begin{array}{l}\text { Chi-Sq. } 30.45 \\
\text { Chi-Sq. d.f } 6 \\
\text { Prob } 0.000\end{array}$ \\
\hline
\end{tabular}

Notes: 1 . The numbers in parentheses present the stand error.

2. $* * *$ and $* * *$ represents statistical significance at $10 \%, 5 \%$ and $1 \%$.

provisions of loans. These findings are consistent with previous literature (Munteanu, 2012; Vodova, 2013). The cost of funding, besides being statistically significant, presents opposite results when the bank liquidity position is measured by two different ratios. The bank cost of funding, in the first case, is positively related to liquidity of the banks whilst it is negatively related to the liquidity of the banks in the second case. Bank size, expectedly, shows opposite results for the period under study. Banks' size, the study reveals, impacts liquidity very differently when analysed by two different measures of liquidity - a finding consistent with Delechat et al. (2012). Deposits of the banks impact liquidity of banks negatively. This is possible and consistent with the study of Dinger (2009) which shows that the relationship as negative between deposits of the banks and the bank liquidity. Profitability of the banks, furthermore, impact liquidity of banks positively, but is 
statistically insignificant. Profitability plays a crucial role in liquidity of banks. In other words, higher the profitability of the banks easier it will be for the banks to hold more liquidity. The findings are consistent with the study of Aspachs et al. (2005). The estimated model explains about $78 \%$ as well as $73 \%$ variations in the dependent variable by the independent variables as confirmed by the value of adjusted R-Square. The above results show that liquidity of the banks in Pakistan for the period under study is impacted very differently when measured by two different ratios. The two measurement techniques provide two impacts, in fact, on liquidity of banks. Separate regression is run for each macroeconomic variable because of the high multicollinearity between them (GDP and UNEM). In case of GDP, the two measures of liquidity shows an opposite relationship. For instance, in the first measure of liquidity, GDP is positively related to bank liquidity, which is consistent with the findings of Bunda and Desquilbet (2008) and Moussa (2015), showing a positive relationship of GDP with liquidity of banks whilst it is negatively related in second measure of liquidity, although remaining statistically significant. The second measure of liquidity is possible when banks in Pakistan supplied excessive loans to customers during the period of 2008 through 2013, findings are consistent with Valla et al. (2006) and Aspachs et al. (2005) which shows a negative relationship between GDP and bank liquidity. The consequences were unbearable when several banks have to merge due to emergence of liquidity problems, hence impacting the aggregate GDP of the country. Furthermore, although statistically significant, unemployment is negatively related to liquidity in the first measure of liquidity. This finding is consistent with the study of Rauch et al. (2010) that shows a negative relationship between unemployment and liquidity of banks in Germany, whilst it is negatively related to the second measure of liquidity. These findings are in consistence with the study of Horvath et al. (2014) that shows a negative impact of unemployment on liquidity of banks, although it is statistically insignificant. This is true because as unemployment increases in the country the demand for loans by customer decline, a case that occurred in Pakistan during the period of study, as shown by the findings of this study. The impact, however, of unemployment on both measures of liquidity remained very low during the period under consideration.

\section{Conclusion, Limitations and Future Direction}

The aim of the current study is to identify the impact of internal factors as well as external factors of bank on banks' liquidity. The study is conducted on banks of 
Pakistan and considered 23 banks over the period of 2007 through 2016. An appropriate panel data model was estimated to serve the purpose of the study.

The results obtained in the paper demonstrated that liquidity of banks can be affected significantly by the independent variables defined in Models 1 and 2 . According to results, cost of funds, capital adequacy ratio and bank size have a positive and significant impact on the liquidity of banks operating in Pakistan. On the other hand, deposits are inversely linked with liquidity in the present study. Simultaneously, profitability of banks has not had any significant impact on banks' liquidity. Simultaneously, the liquidity of banks in Pakistan is impacted very differently by GDP when the two measures of liquidity are employed. Finally, unemployment, although statistically significant in the first specification and insignificant in the second specification, also affect liquidity of banks operating in Pakistan very differently. The impact, however, of unemployment on both measures of liquidity remained very low during the period considered in the study.

We expect that the findings of the study would be indeed useful for all relevant stakeholders such as the banking sector itself, the SBP and the aggregate economy. The authorities are suggested to monitor the identified internal factors that have negative influence on banks liquidity in order to reduce the chances of bank run and should study the banking sector to prevent further deterioration of banking liquidity which, if not addressed timely, might translate into liquidity crunch and crisis. This study, without any doubts, has limitations in terms of unavailability of data of several banks. The researchers, therefore, excluded the banks which either merged with other banks and which had no data available for analysis purpose. The study recommends researchers to study and research whether liquidity problems in Pakistan are same for each category of banks or whether liquidity has created any problems and ripple effects for the national economy. Furthermore, it is of utmost significance to investigate whether holding of liquidity (for example $43 \%$ as shown in this study) has created any additional costs for the banks in the short and medium periods. The study can be extended to explore the impact of internal factor on liquidity of banks as separately (such as the impact on liquidity of small, medium and large banks).

\section{Acknowledgments}

The authors would like to thank Dr. Muhammad Asim Afridi for his guidance. 


\section{Declaration of Conflicting Interest}

The authors declared no potential conflicts of interest with respect to the research, authorship, and publication of this article.

\section{References}

Ahmad, A., Malik, M. I., \& Humayoun, A. A. (2010). Banking developments in Pakistan: A journey from conventional to Islamic banking. European Journal of Social Sciences, 17(1), 12-17.

Ahmed, N., Ahmed, Z., \& Naqvi, I. H. (2011). Liquidity risk and Islamic banks: Evidence from Pakistan. Interdisciplinary Journal of Research in Business, 1(9), 99-102. Retrieved from http://cif.ciitlahore.edu.pk/Files/PA8.pdf

Alger, G., \& Alger, I. (1999). Liquid assets in banks: Theory and practice (Working Paper No. 446). Boston: Boston College Department of Economics. Retrieved from https://ideas.repec.org/p/boc/bocoec/446.html

Arif, A., \& Anees, A. N. (2012). Liquidity risk and performance of banking system. Journal of Financial Regulation and Compliance, 20(2), 182-195. doi: 10.1108/13581981211218342

Aspachs, O., Nier, E. W., \& Tiesset, M. (2005). Liquidity, banking regulation and the macroeconomy. Evidence on bank liquidity holdings from a panel of UKresident banks. Bank of England Working Paper. doi: 10.2139/ssrn.673883

Aspachs, O., Nier, E. W., \& Tiesset, M. (2005). Liquidity, banking regulation and the macroeconomy. doi:10.2139/ssrn.673883

Basel Committee on Banking Supervision (2013). Basel III: The liquidity coverage ratio and liquidity risk monitoring tools. Retrieved from https://www.bis.org/publ/bcbs238.htm

Berger, A. N., \& Bouwman, C. H. (2009). Bank liquidity creation. The Review of Financial Studies, 22(9), 3779-3837. doi: 10.1093/rfs/hhn104

Bhattacharya, S., \& Thakor, A. V. (1993). Contemporary banking theory. Journal of Financial Intermediation, 3(1), 2-50. doi: 10.1006/jfin.1993.1001

Bonfim, D., \& Kim, M. (2012). Liquidity risk in banking: is there herding? European Banking Center Discussion Paper, 2012-2024.

Bonner, C., Van Lelyveld, I., \& Zymek, R. (2015). Banks' liquidity buffers and the role of liquidity regulation. Journal of Financial Services Research, 48(3), 215234. doi: 10.1007/s10693-014-0207-5

Bunda, I., \& Desquilbet, J. B. (2008). The bank liquidity smile across exchange rate regimes. International Economic Journal, 22(3), 361-386. doi: 10.1080/ 10168730802287952 
Chen, I. J., \& Phuong, N. L. (2014). The determinants of bank liquidity buffer. Retrieved from https://mediacast.blob.core.windows.net/production/Faculty/ StoweConf/submissions/swfa2014_submission_9.pdf

Choon, L. K., Hooi, L. Y., Murthi, L., Yi, T. S., \& Shven, T. Y. (2013). The determinants influencing liquidity of Malaysia commercial banks, and its implication for relevant bodies: Evidence from 15 Malaysian commercial banks. Retreived from http://eprints.utar.edu.my.

Delechat, C., Arbelaez, C. H., Muthoora, M. P. S., \& Vtyurina, S. (2012). The determinants of banks' liquidity buffers in Central America (Working Paper No. 12-301). International Monetary Fund.

Diamond, D. W., \& Rajan, R. G. (2001). Banks, short-term debt and financial crises: Theory, policy implications and applications. Carnegie-Rochester Conference Series on Public Policy, 54(1), 37-71. doi: 10.1016/S01672231(01)00039-2

Dinger, V. (2009). Do foreign-owned banks affect banking system liquidity risk? Journal of Comparative Economics, 37(4), 647-657. doi: 10.1016/j.jce.2009.04.003

Distinguin, I., Roulet, C., \& Tarazi, A. (2013). Bank regulatory capital and liquidity: Evidence from US and European publicly traded banks. Journal of Banking \& Finance, 37(9), 3295-3317. doi: 10.1016/j.jbankfin.2013.04.027

Horváth, R., Seidler, J., \& Weill, L. (2014).Bank capital and liquidity creation: Granger causality evidence. Journal of Financial Services Research, 45(3), 341-361. doi: 10.1007/s10693-013-0164-4

Jenkinson, N. (2008). Strengthening regimes for controlling liquidity risk: Some lessons from recent turmoil. Euromoney Conference on Liquidity and Funding Risk Management Vol. 6, (pp. 9-14). London: Bank of England.

Lartey, V. C., Antwi, S., \& Boadi, E. K. (2013). The relationship between liquidity and profitability of listed banks in Ghana. International Journal of Business and Social Science, 4(3), 48-56.

Matz, L., \& Neu, P. (Eds.). (2006). Liquidity risk measurement and management: a practitioner's guide to global best practices (Vol. 408). Singapore: John Wiley \& Sons. doi: 10.1002/9781118390399

Moussa, M. A. B. (2015). The determinants of bank liquidity: case of Tunisia. International Journal of Economics and Financial Issues, 5(1), 249-259.

Munteanu, I. (2012). Bank liquidity and its determinants in Romania. Procedia Economics and Finance, 3, 993-998. doi: 10.1016/S2212-5671(12)00263-8

Rauch, C., Steffen, S., Hackethal, A., \& Tyrell, M. (2010). Determinants of bank liquidity creation. 
Sabahat, S. (2017). Estimating liquidity created by banks in Pakistan (Working Paper No. 86). State Bank of Pakistan, Research Department.

State Bank of Pakistan (2017). Quarterly performance review of banking system. Karachi: Author.

Singh, A., \& Sharma, A. K. (2016). An empirical analysis of macroeconomic and bank-specific factors affecting liquidity of Indian banks. Future Business Journal, 2(1), 40-53. doi: 10.1016/j.fbj.2016.01.001

Tahir, M., Shah, S. S. A., \& Afridi, M. A. (2016). Assessing nature of competition in banking sector of Pakistan. The Journal of Finance and Data Science, 2(4), 244-253. doi: 10.1016/j.jfds.2017.04.00

Valla, N., Saes-Escorbiac, B., \& Tiesset, M. (2006). Bank liquidity and financial stability. Banque de France Financial Stability Review, 9, 89-104.

Vodov, P. (2013). Determinants of commercial bank liquidity in Hungary. eFinance, 9(3), 64-71. 